\title{
HUMAN OCUPATIONS AND ENVIRONMENT AT LAST PLEISTOCENE IN THE NORTH OF SOUTH AMERICA
}

\section{Mario Alonso Bermúdez Restrepo}

Professor / researcher in Archeology area in the Department of Anthropology and Sociology of the University of Caldas. Student of the Master's degree in Sciences of the earth in the University of Caldas and student of the Doctorate in FACSO National University of the Center of the province of Buenos Aires. Coordinator of the laboratory of archeology of the Caldas University. Colombia

Email: mario.bermudez@ucaldas.edu.co

\section{Summary}

The environmental context at the end of the Pleistocene has been the focus of anthropological research on the population movement that resulted in settlement of the American continent. We present an analysis of environmental conditions that could have affected the movement of humans and the subsequent population expansion into Central America and northern South America. Our research integrates Archaeological a palaeoecological literature and the regional physiographic characteristics during the end of the Pleistocene through the beginning of the Holocene (Last Glacial Maximum to the first part of the Holocene Hipstemal). We further evaluate question the models of dispersion and adaption of the ancient communities to the environmental challenges that faced the first settlers of the New World. 
Keywords: Pleistocene, LGM, Human Dispersion, Sud America

\section{OCUPACIONES HUMANAS Y MEDIOAMBIENTE AL FINAL DEL PLEISTOCENO EN EL NORTE DE SURAMÉRICA}

\section{Resumen}

El contexto medioambiental de finales del Pleistoceno ha sido uno de los focos de discusión para quienes estamos interesados en los movimientos poblacionales que desembocaron en el poblamiento del continente americano. Se presenta en este artículo un análisis de las condiciones medioambientales que pudieron afectar la dispersión humana en el continente, en especial el paso por Centro América y el Norte de Suramérica. En él se muestran, con base en la literatura reciente, algunas de las características fisiográficas del período final pleistocénico y el inicio del Holoceno, desde el Último Máximo Glaciar hasta la primera parte del Hipsitemal holocénico, además se dejan interrogantes sobre los modelos de dispersión y adaptación de las comunidades humanas a los entornos ofrecidos a los primeros pobladores de este nuevo mundo.

\section{Palabras Clave:}

Peistoceno, UMG, Dispersión humana, Suramérica

\section{Introduction:}

The first settlement and the human scattering in the South American continent are troubles of long discussion in archeology. Since the beginning of the twenty century, with the appearance of the lithics Folson y Clovis in North America and some findings of materials in the surface or in open contexts in South America, like projectile points in Bahia Gloria (ReichelDolmatoff, 1986), Palli Aike in Patagonia (Bird, 1938 in Fiedel, 1996) between others, the discussion turn around to the dates and way of resources catchment of the hunter specialized in megafauna (Kelly, 1995). Early these century the discussion have been feedback by different proposals based in new data obtained in deposits with early dates, what has generated hypothesis and theories about the demographics movements that settled the 
subcontinent (Lanata 2008; Sheinsohn 2003, Goebel et al, 2008, Anderson, Bissett, and Yerka, 2013), between a lot. Today artefactual evidences, like sets of lithics elements, among the ones that includes projectile points and bifacial artifacts also unifacial expeditious tools and modified by use, made in different raw materials, added to the paleoenvironmental data available in disposals and its contexts, it allow to elaborate hypothesis about one settlement that goes further than the Holocene (Correal and Van del Hammen, 2001; Stothert and Sánchez, 2011; Dillehay, 2008; Araujo et al, 2012, Boeda, et al. 2014, López, 2019). Even evidences like lithics artefacts retouched founded in stratigraphic unities (Halligan et al. 2016) and in others hints (Brook et al, 2013) they could indicate that groups of hunters and foragers been present since the Last Glacial Maximum in different ambiences, from the beach and the savannah until the Andean mountains, making modifications in the environment.

The reports of analysis of different environmental proxies like pollen and lacustrine sediments (Velásquez and Hooghiemstra, 2013; Flantua et al, 2014), reveals that the environmental mosaic from the endings of Pleistocene was suitable for the population movements in the South American continent.

\section{Relations Homo - Environment, model and hypothesis for Pleistocene}

Theories about behavior of the first Homo, have been subject of interest of anthropology, paleontology, archeology and primatology, like sciences that deal with evolution, between other problems. In this interest to elaborate hypothesis about the adaptative models, from the ethology of primates, have been demonstrated that some of the superior primates, evolutionarily close to us, sustain complex organizations relative to the hunters - gatherers from low density studied by the anthropology (Hohmann and Fruth, 2003; Sapolsky, 2006). And from archeology and paleoanthropology have been sowed data that argument than the gender Homo, from the apparition in the planet from approximately 2 million years, to the modern humans, have been a way of social organization and economical production similar to the primate's non-human (Kelly, 1995; Johnson and Earle, 2003: Mithen, 1996). Before the last Pleistocene interglacial, homo sapiens, taking advantage of the bioclimatic conditions (we will see later), spread by the African continent (Richter et al, 2017). their adaptative model continuous been apparently the one of small groups of low density, with a mode of production of immediate consumption, denominate like of "hunters - gatherers" (Lee, 1979), 
characterized by the catchment and consumption of the offer of environment, or economy of subsistence. The strategies of survival consist in maintain a population controlled of no more than 100 individuals, accomplished by different media; continuous residential mobility, in case of environment with a low productivity, or a logistic mobility, in case of a productive environment; a flexible diet and ductile; added this, the social relations was dominated by a generalized reciprocity, in which give, receive and return become a rule to the social cohesion (Johnson and Earle, 2003); finally, technology continued been simple; in the archeological register barely outlast the bifacial multipurpose lithics artifacts and some tools in materials like pole, bone or shell, but these do not implicates that the elaboration of a of a complex equipment in biodegradable like wood and fibers been not present (Renfrew y Bahn, 2011).

In the course of the last glaciation Homo sapiens continues his evolutive/adaptative process. In this period apparently, he complements the cultural specialization, follow the model (commented in the last paragraph) that made successful to others congeners. The process could be influenced by his coadaptation with others Homo, with others animals and plants in semi open environments by way of "patches" or "shelters" (Stewart and Stringer, 2012) or also the concept of "niche construction" (Laland and Brown, 2006), which at the moment of climatic improvements (interstates) could expand to "corridors" or "galleries" and permit the continental or transcontinental mobility, like the colonization of Australia or America.

\section{The environment in the ending of Pleistocene}

Since approximately 2,58 million of years the planet entered in a period of cooling, caused principally by astronomic phenomena, that manifest cyclically, those are known cycles of Milánkovitch (Bradley, 1999; Lee and Poulsen 2009). Although the general cooling of the system is the main characteristic of the climate in the Pleistocene this do not implies that this time could be qualified like of climatic stability, by the contrary, the proxy registers show fluctuations between coolest periods (statewide), dry or wet and others warmer (interstates) also with fluctuations of humidity, that happen cyclically in times not strictly periodic (Masson-Delmotte et al, 2010).

The isotopic register from $\delta^{18} \mathrm{O}_{\mathrm{atm}}(\%)$, the concentrations of Deuterium $\left(\delta \mathrm{D}_{\mathrm{ice}}\right)$ and greenhouse gases trapped in the columns of ice of the sampling of Vostok in Antarctic (Petit et 
al, 1999), the geochemical register of sediments transported by the ice (IRD, "Heinrich Events"), like carbonates, isotopic composition of $\mathrm{Nd}-\mathrm{Sr}-\mathrm{Pb}$, among others (Hemming, 2004), added to the biotics evidences like pollen obtained in the sampling of Funza by por Hooghiemstra and Rahn (1998), the sampling of the perforations in the bottom of the Peten lake (Hodell et al 2006), allow us to conclude that in certain moments the mainland availability to the dispersion of flora, fauna and the occupation of human species, change considerably.

For the ending of Pleistocene, does around about $125 \pm 5$ thousand years, planet suffer a sudden heating and a short stability known like interglacial Eemiense u OIS 5e in Europe, which hard around approximately 11 thousand years, until $114 \pm 5$ thousand years before of the present (Muñoz-García et al, 2007; Uriarte, 2010; Lowe and Walker, 2015). This period, considered like the interglacial of longer duration than those commonly occurred in the glaciation's era, was characterized by a temperature between $3 \circ$ and $5 \circ \mathrm{C}$ upper than now, and high levels of humidity, compared with the registered Before and after (Riouala and Mackay, 2005). The principal consequences were the expansion of the tropical forest until the middle latitudes, the sabanization of part of the Sahara and an increase of the sea level higher than was present in the maximums of the Holocene (Uriarte, 2010). These conditions bioclimatic allowed than Homo extended their territories of occupation by all the intertropical and probably propitiate the final evolution of the sapiens in the north of Africa, according the last dates reported by the institute Max Planck (Richter et al, 2017). The expansion of a tropical environment relatively stable, impulse the success of the specie, even if not generate a different way of organization / adaptation from the one already developed by his like-minded people from the remote past. After the Eemiense, the orbital cycles and other astronomical conditions made that climate comes cool again, the increasing of albedo caused by a bigger ocean icefield, the shorter summers and longer winters, the diminution in the circulation of thermohaline, would flow in a new glacial period, in which the ice sheets extended until the medium latitudes (Bradley, 1999; Tarbuks and Lutgens 2005; Lowe and Walker, 2015). In the course of the last glaciation, like was noted before, the climate changes continue fluctuating from very cool (statewide) to some less cool (interstates), unreached temperatures nor temporalities of interglacial. For the final of the glaciation there was a last global cooling known like the Last Glacial Maximum o (LGM) occurred between $23 \pm 1$ and $19 \pm 1$ thousand 
years before the present, with some local variations well traced (Bush et al, 2009). This cooling affects stronger to the high latitudes, with greater forcefulness in the north hemisphere.

The consequences of LGM were variated, especially if been related with the spread of human species. The growing of accumulation of ice in the mantle Laurentino y Finoescandinavo, and in the high mountains tropical and subtropical, in which the snowfall been condensed until made layers of ice of thickness bigger than 200 meters, generates a decrease of the level of the sea that reach between 120 and 140 meters under of the current level (Clark et al. 2004, Lowe and Walker, 2015), this like product of the evaporation of water from the tropical seas and it's not return to the natural liquid cycle; so the "mainland" occupied by the ice in the north and the continents, was compensated with the earth exposed in littorals of other latitudes (Bracco et al, 2011; Williams, 2009), including the opening of natural bridges between continents and islands (Uriarte, 2010; Anderson et al. 2013) and the expansion between others from Antarctica (Grobe et al, 1993).

In Central America and in the north South America, the level of the sea under of 120 meters, produce a drastic change in the landscape. In the Caribe the exposition of the continental platform was much more significative than in Pacific, in both ocean costs the new lands were colonized by vegetation and fauna. Also, the level base for the rivers (tidal line) situated topographically so low, made than the curve of gradient of the cause increase considerably, especially in the short steams from the mountain ranges closer to the cost line, which generates resilient processes differenced, from the excavation in the bottom of the valleys and changes in the conformation of the structures of the catchments, that is the case from the fluvial evidences of the Magdalena river at the high of Momposina depression. (Toro y Hermelin, 1995; Velásquez y Hooghiemstra, 2013).

Other significant change that could influence over the movement of populations and colonization of the human beings and other animal species in the north of south America have to be with the distribution of the vegetal mosaic. Pollinic evidences shows that the forest cover of the mountain migrated (Toro y Hermelin, 1995; Velásquez y Hooghiemstra, 2013). As the snowy invades the high tops of the mountains under $4.000 \mathrm{~m}$, the subparam and the forest Andean and Sub Andean moved until $1500 \mathrm{mt}$ by the hills of the mountains, while that, in the bottom of the of the valleys of low height (under the $900 \mathrm{mt}$ ), like the one of Magdalena and 
Cauca and its tributaries, and the coast savanna, the vegetation of the tropical forest, more or less wet stays almost without variations (Hooghiemstra and Rahn, 1994; Marchant et al 2002). Toward the $19 \pm 1$ thousand before the present, starts the process of deglaciation (Bush et al, 2009). There are no hard data about in which hemisphere its start, the behavior of the different proxies at the north and south are not coincident altogether, this make also that is no so clear if are contemporary or not in both (Lowe and Walker, 2015; Thomas, 2008). Its causes are in a discussion, there are different hypothesis, from the astronomical cycles of Milánkovitch, the changes on the flow of the ocean currents and the winds in the Atlantic North (He et al. 2013) and the effects of the greenhouse gases like $\mathrm{CO}_{2}, \mathrm{CH}_{4}, \mathrm{~N}_{2} \mathrm{O}$ and the steam of $\mathrm{H}_{2} \mathrm{O}$ (Saltzmank, and Stievenard, 1999), other argument that could serve as a cause is the diminution of albedo and icefield of the ocean (Roberts, 1998). This progressive warming, that generates thaws of the mantles, is related directly related with the Heinrich events, it also has direct effects on the sea levels, which was increasing gradually until get the actual level in approximately $9 \pm 1$ thousand years, it means at the beginning of the Holocene (Clark et al, 2004; Alley et al, 2005). At the moment of beginning of the deglaciation, immediately after of the UMG, since approximately 19 thousand years, there were already in the north of the South America continent and in Panama isthmus groups of hunters - gatherers (like will show latter). These evidences are coherent with dates reported from other places in South America like El Jobo, Monteverde, Pedra Furada and Los Toldos.

\section{The effects of the Younger Dryas (YD) in the region}

The process of deglaciation that starts in the $18 \pm 1$ thousand before the present and it extended in the period Bølling-Allerødin the north hemisphere, has a short feedback surrounding the $12,9 \pm 0,5$ thousand by different causes, in which the register show that cold temperatures were resumed during 1,2 to 1,4 thousand years (Rincón y Martínez, 2004). The dates in different subregions in the intermediate area match with a time of cooling and drying. Such is the case of the mountain ranges of the north of South America, which reports allowed to reconstruct pulses more or less cool, in which be interspersed statewide and interstates and that for this period is denominated statewide of the Abra (Van der Hammen, and Hooghiemstra 1995; Velásquez and Hooghiemstra, 2013). The eastern planes of Colombia 
and Venezuela (Behling and Hooghiemstra 1999) Center America and Panama isthmus, where is observed a drying and the going up of the sea level at the end of this period when starts the wet phase that characterized the entrance of the Holocene (González., Urrego y Martínez. 2006). In the case of high valley of the Cauca River, the temperature is not reduced significatively, but the vegetation in this time is characterized by dry forest (Berrío et al, 2002)

In sum the dates palynological and sedimentary, indicates that in this period is characterized by ambient less dense by the developed in the actual conditions of humidity and temperature, in medium heights and low heights of the mountain ranges could presents successions of forest of gallery more permanents, that also could be indicating that the change of the vegetal mosaic is not so abrupt like it was thought out (Marchan et al 2002).from the other hand the actual results continue holding up the hypothesis that in medium heights and highs of the eastern and central mountain ranges, in Colombia and the surrounding regions occurs a cooling between the 11 thousands and 9,5 thousands that coincide with the conditions of the European Younger Dryas (Van del Hammen and Hooghiemstra, 1995. Velásquez and Hooghiemstra, 2013. Urrego et al, 2015). Also, in the high latitudes of the south hemisphere, a similar Phenomenon is represented in the perforations made in the Antarctic, to the ones that are denominated 'Antarctic cold reversal', (Ingólfsson, 2004).

\section{Human occupation and Archeological places of the transition Pleistocene - Holocene in the north of South America.}

Since the decades of the $60 \mathrm{~s}$ and $70 \mathrm{~s}$ of the last century, different paleoindios archeological places dated in the in the transition Pleistocene - Holocene, were reported in different latitudes of the American continent, from Bluefish Caves in Canada place that initially was divulgated with a temporality of 14 thousand years, that was replanted recently by Bourgeon et al (2017) remounting the temporality to the $19,650 \pm 130{ }^{14} \mathrm{C}$ BP (calibrated to years calendar to 24 thousand years AP), passing by the place of Pubenza (Correal and Van der Hammen, 2001), whose radio carbonic age it dated back to $16550 \pm 150{ }^{14} \mathrm{C} \mathrm{BP}$ (calibrated to years calendar of 19 thousand years AP) until Monte Verde in Chile, with a temporality $12,290 \pm 60 \mathrm{C} 14$ yr B.P. calibrated to years calendar in 18,5 thousand years AP (Dillehay et al., 2015). 
Even so, the majority of the places that overpass the holocenic ages have had contradictors, so much in archeology like in the environmental science that prefer the conservative dates and the lithic sets associated to the Clovis tradition. But as an example, like observe in the figure 1, ending the century XX and in de beginning of the XXI, more than twenty places, situated from the Panama isthmus until the north west of South America, report Pleistocene dates, as much in the Andean ambiences like in the savannas and places where today are ubicated tropical forests (Bermúdez, 2017).

Based on the distribution of the places, in the associations of the lithics sets and the results of researches about the dominants paleoenvironments at the end of the Pleistocene, authors like Fiedel, (2000), Surovell (2003), Lanata et al (2008) and Goebel, Waters and O’Rourk (2008), between others, have proposed general models of settlement of the continent. All of them have taken like starting point the ingress by the bridge of Beringia. Others researchers like Kitchen, Miyamoto and Mulligan (2008) consider that the dates paleoclimatic and paleo ecological, so much in these temporality like in some posterior (medium Holocene) are not complete coherent, like It was presented in a previous paragraph, and include some prefer to elaborate alternative theories about the process of settlement of the continent (Faught, 2008; Anderson et al. 2013) 


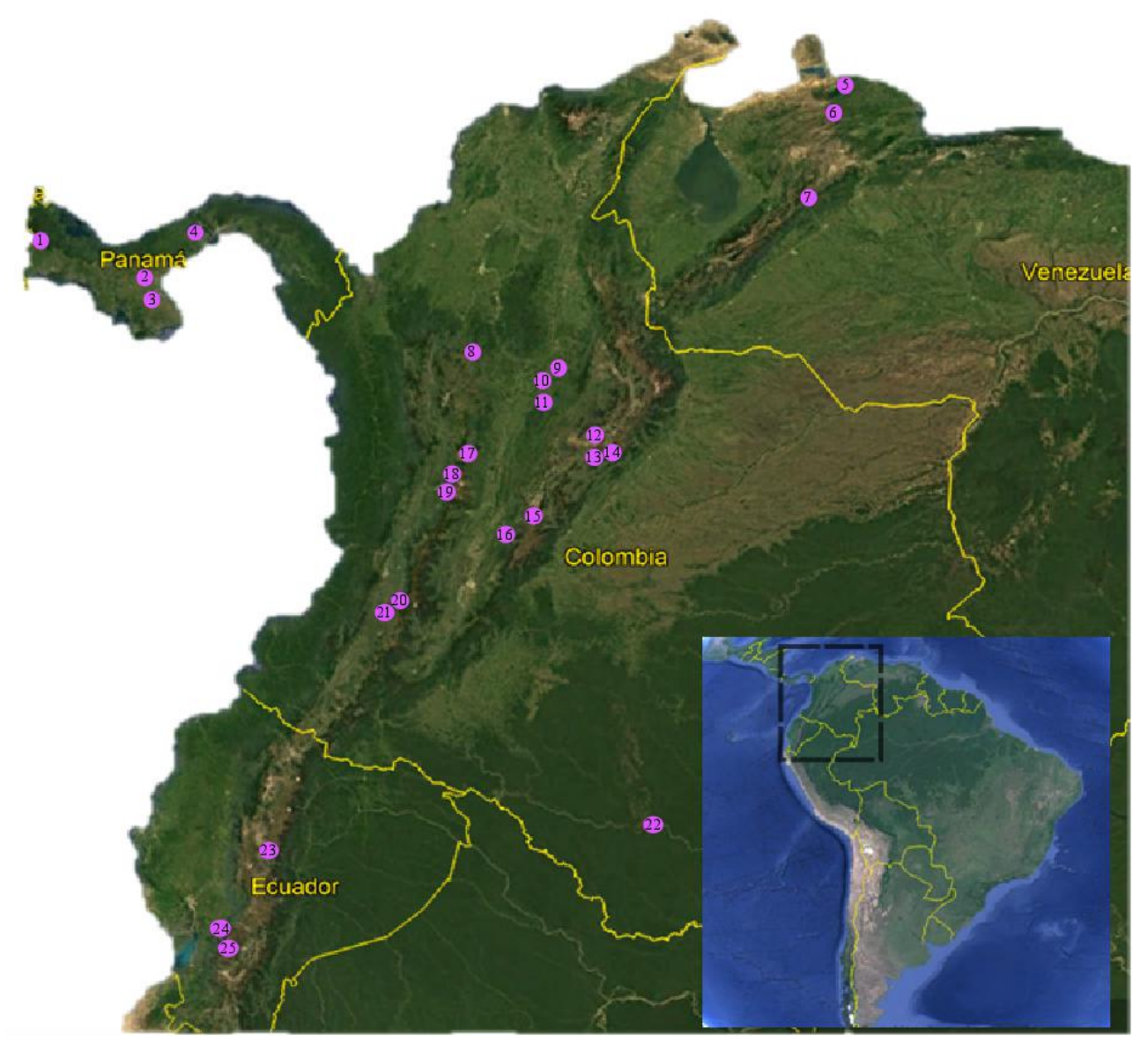

Image 1. Ubication of places dated between the end of Pleistocene and the early Holocene in the north west of Sud America and Panamá isthmus: 1. Turrialba 2. La Yeguada 3. Los Vampiros. 4 Lake Maden. 5. TaimaTaima 6. El Jobo. 7. El Vano. 8 Porce. 9- Yondó. 10. La Palestina; 11- San Juan de Bedout. 12. El Abra. 13. Tequendama.14. Tibitó. 15. El Totumo. 16. Pubenza 17.El Jazmín 18.Cuba. 19.La Mikela. 20.La Elvira. 21.San Isidro. 22.Araracuara. 23.El Inga.; 24. Cubilán 25. Chobshi (taked from Bermúdez, 2017)

According to dates reported in the Amazon by Van der Hammen y Absy (1994), in the caribe Center American by Hodell et al (2008) and in Panama by González et al (2006) during the transition Pleistocene - Holocene, predominates a more dry climate, that make change the environmental mosaic. In the region the proportion between savannah, the tropical forest and the coast ambiences would be so different from the actual, the coast line would be varying according to the rain and the thaw, what would influence in the movement of populations of the biota, including the human species. In the low lands the extension of Savannah prevailed over the humid tropical forest (Marchant et al., 2002), And include could generates, in the dry areas, aridic landscapes, in which herbaceous vegetation have a higher percentage and the galleries of the forest roll back (Behlingy Hooghiemstra, 1999) and in the high lands the expansion of the perpetual snows and the fells forest also was significative like we saw 
previously (Flantua et al 2014). This environmental behavior could be related with the movements in the intertropical Zone of Confluence (McGee et al, 2014).

If we consider the physiographic panorama of the deglaciation, in which the rise of the sea level was prolonged until the early Holocene, with the well-known pulse of the Younger Dryas (Alley et al, 2005), The environmental changes, the local climatic pulses, y they are added the evidence founded in the twenty five places dated between the late glacial abd the beginning of the Holocene in the north of South America (Bermúdez, 2017), it must be understood that much of the places archeological Paleoindians, or of the age Pleistocene, should be today in levels that was cover by the oceans Pacific and Atlantic nearby the coast platform (Anderson et al. 2013). Other problem has to be with the continental geomorphological dynamics, since many of the places could have suffer removal processes, could have been retransported, or they find buried by sediments of slope, or fluvial deposits, what implies its destruction partial or total or its difficulty to be observed or detected, like was proposed in a previous essay (Bermúdez, 2011).

Even so, like we have been arguing, the ecological conditions in the continent South American, and in general all America at the ending of Pleistocene, including the UMG and the YD, were favorable to the human groups bring out all the adaptative advantages that they accumulate during millenniums in adverse conditions of the glacial era, which had to do with the flexibility in the model to get resources (economy of subsistence) and the sociocultural organization (familiar Organization). The cloud of dots that represents to the Paleoindians archeological places, demonstrates that the strategies of the hunters - gatherers were successful from the oceanic costs, until high mountains and from media latitude until the Ecuador (López 2008; López y Cano, 2011).

Like final argument we could affirm that, the distribution of the archeological places reported for the temporality comprehend between the late Pleistocene and the initial Holocene in the north of Sud America, it would indicating that the movements of the human populations in this period were continuous (Waters and Stafford, 2013; Borrero, 2015), this like a adaptative response to the environmental offer, between niches, patches and shelters, and the human capacity to occupy, make use of it, share with others or defend it. Also, some dates support that we can conclude that the populational density could be higher than thought (Kitchen, Miyamoto and Mulligan 2008). 


\section{By way of hypothesis in perspective}

As it has been showing, the registers of the human occupations could be sub represented significatively because of the cultural and environmental dynamics occurred at the moment of the human use of the landscape, or by the events natural or cultural happened after the abandon of the places (Butzer, 1989). These dynamics were propitiated by different systemic pressions, which include the global climatical changes like the statewide and interstate of the Pleistocene, the warmer of the Hypsitermal from the beginning of the Holocene; the regional balances and the anomalies, like the ENSO and the migration of the ITCZ, and local events like neotectonics and vulcanism.

This phenomena at the same time provoked changes in the level of the sea (tectono-eustasismo y glacioeustasismo), rainy seasons or abnormal droughts with their usual floods, storms and hurricane winds. This kind of inputs generates processes of erosion and sedimentation of different sizes. To this we could added a set of geomorphodynamics in the sheds and in the foothills, that produce mass movements able to modeling the landscape and remodel the surfaces, finally the active vulcanism in this period, that could remove and/or bury complete places under pyroclastic fluids of high energy, generates lahars, or buries by mantles of tetras due to the falling of ashes.

To complement, if rebuilds the map of the South American continent at the end of Pleistocene, from the moment of the maximum low of the level of the sea in the UGM until the Younger Dryas, having in account the results presented by Clark, et al. $(2004 ;)$ y por Balsillie, and Donoghue (2004), could be observed a cost line very different to the actual one. Like it was mentioned the minimum of the level could had reached the $140 \mathrm{~m}$ by below the higher level registered in the Holocene hipsitermal.

If follow the level lines from 100 deep in the maritime platform of the South American continent, the contour would be completely different to the one presented today, especially in the Atlantic basin, in which the subaquatic relief have less slope than in Pacific, with the exceptions of Panama and Guayaquil gulfs, even if this was affected significatively (Anderson et al. 2013). Returning to the Atlantic, from the north west, the Darien gulf and the Atrato river would conform a delta very different, with a bigger extensions of emerged lands, the 
Colombian central Caribbean cost will be deformed until reach the nearby archipelagoes, equally the deltas of the Sinu and the Magdalena rivers be extended for several kilometers, the Guajira peninsula would have also a much larger extension, the Venezuela gulf probably disappear giving origin to lakes and marshes, equal with the Maracaibo lake than furthermore of disconnect from the ocean would form a interior basin, the Paraguana peninsula and other Venezuelan costs would connect with some islands from las Antillas the delta of the Orinoco would prolongate over the platform for more than $50 \mathrm{kms}$ (figure 2) equal than the coast plains at north east, from de river mouth of this until de Amazon. Finally, the coast line would expand ostensibly from Rio until la Patagonia, making that the rivers increase its basins and deltas.

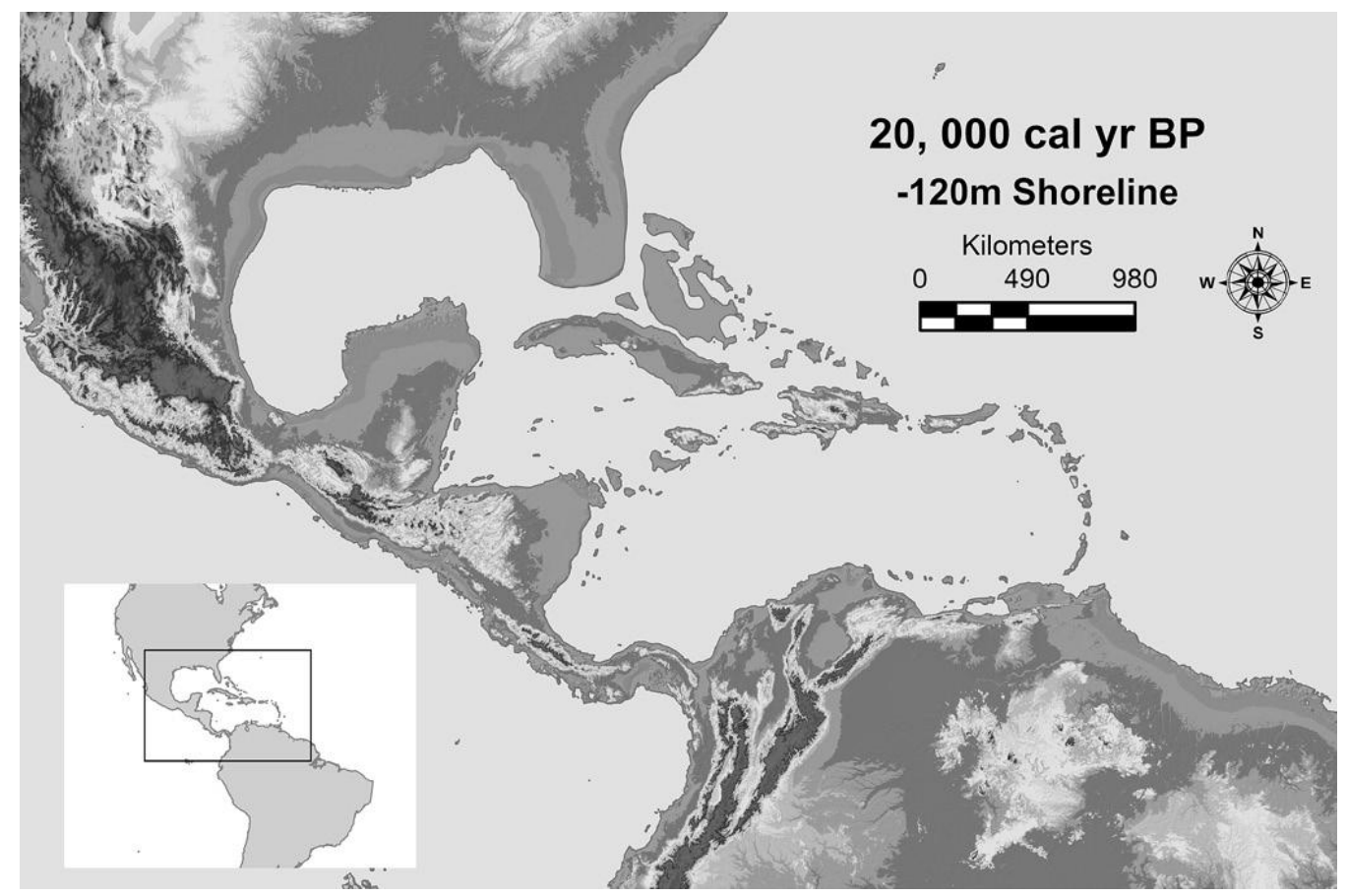

Image2. Simulation of the coast line in Center America and the north of South America in the UMG of the last Pleistocene. (From Anderson et al. 2013)

According dates obtained in different latitudes in the continent, a climate with less precipitations during the period in mention would make change the environmental mosaic, proportions between savannah and steppes, the tropical forest and galleries of woods and the coast ambiences of mangle and of marsh, would be very different to our contemporary. Like was exposed, the extension of the savannah overpasses the actual lines of the humid tropical forest, and include could generate, in the areas with most exposition to insolation and the winds, the driest zones, aridic landscapes, fields of dunes and Eolic deposits. This 
environmental behavior could have too much detonators but the most responsible were the changes in duration and intensity of the cycles of Niño/Niña and movements more or less extensive of the zone of intertropical Confluence.

To finish cannot be neglected the complexity of the human decisions in the medium and long term. Like It was commented in one of the paragraph, the eclectic economy of our ancestors, which was based principally in the opportunism in the moment of resources catchment (a strategy probably inherited of the predecessors humans and non-humans) allows them the adaptative successful in the new tropical territories. The populational density and technology expeditious in materials easily degradable also is a variant to take in account in the moment of evaluate low concentration of places associated to this period and to these modes of subsistence.

Even if the investigations have thrown a significative base of data, to the solutions or at least the refinement of the hypothesis about this problem, they become necessary researches in continuous corridors by transdisciplinary teams with common objectives. A detailed sampling in cultural contexts and non-cultural, the selection and control of the proxies to environmental rebuilt and the relation of the human's groups with the ecosystems and their responses, allow in a no so far future in better the resolution in the moment of interpretation. Just applying adequate methodology, we could understand the dynamics between the groups of humans and ambiences, more when problem includes adaptation and adaptability of one species that is at the same time change factor.

\section{Bibliografía}

[1] Alley, R. Clark, P, Huybrechts, P and Joughin I. (2005) Ice-Sheet and Sea-Level Changes. Science Vol 310

[2] Anderson, D. Bissett, T. and Yerka, S. (2013) Cap. 11 The Late-Pleistocene Human Settlement of Interior North America: The Role of Physiography and Sea-Level Change. In Paleoamerican Odyssey. Center for the Study of the First Americans, Texas A\&M University, Editors: Kelly E. Graf, Caroline V. Ketron, Michael R. Waters, pp.183-203 
[3] Araujo, A. Neves, W and Kipnis, R. (2012) Lagoa Santa revisited: an overview of the chronology, subsistence, and material culture of paleoindian sites in eastern central Brazil. Latin American Antiquity 23(4), 2012, pp. 533-550

[4] Balsillie, J. H., and J. F. Donoghue 2004 High Resolution Sealevel History for the Gulf of Mexico since the Last Glacial Maximum. Florida Geological Survey Report of Investigations 103. Tallahassee, Florida.

[5] Bermúdez, M. 2010. Dinámicas geomorfológicas de piedemonte y procesos de transformación de sitios arqueológicos en el Magdalena Medio caldense. En RevistaVirajes. Na 12. Manizales.

[6] Bermúdez, M. (2017) Medioambiente pleistocénico y ocupaciones humanas en el valle medio del río Magdalena, Colombia. En Bermúdez, M. (comp.) Arqueología y Medioambiente en el Magdalena Medio. Universidad de Caldas. Manizales.

[7] Behling, H. y Hooghiemstra, H (1999) Environmental history of the Colombian savannas of the Llanos Orientales since the Last Glacial Maximum from lake records El Pinal and Carimagua. Journal of Paleolimnology. 21

[8] Berrío, J. Hooghiemstra, H. Marchant, R y Rangel, O. (2002) Late-glacial and Holocene history of the dry forest area in the south Colombian Cauca Valley. Journal of Quaternary Science. Vol. 17

[9] Boeda, E., Clemente-Conte, I., Fontugne, M. y Lahaye, C. (2014). A new late Pleistocene archaeological sequence in South America: The Vale da Pedra Furada (Piauí, Brazil). Antiquity Vol 88.

[10] Borrero L.A. (2015) Moving: Hunter-gatherers and the cultural geography of South America. Quaternary International 363. 126-133

[11] Bourgeon L, Burke A, Higham T (2017) Earliest Human Presence in North America Dated to the Last Glacial Maximum: New Radiocarbon Dates from Bluefish Caves, Canada. PLoS ONE 12 (1): e0169486. doi:10.1371/journal.pone.0169486

[12] Bracco R. Inda, H., García-Rodríguez, F y Panario, D. (2011). Niveles relativos del mar durante el Pleistoceno Final- Holoceno en la costa del Uruguay. En El Holoceno en la zona costera de Uruguay por Felipe García Rodríguez (ed). CSIC, Universidad de la República. Montevideo

[13] Bradley, R (1999) Paleoclimatology. Reconstructing Climates of the Quaternary. Second Edition. Academic Press, an imprint of Elsevier. San Diego, CA 
[14] Brook, G, Mancini V, Franco N, Bamonte F y Ambrústolo P. (2013) An examination of possible relationships between paleoenvironmental conditions during the PleistoceneeHolocene transition and human occupation of southern Patagonia (Argentina) east of the Andes, between 46을 52 o S Quaternary International 305

[15] Bush, M; Correa-Metrio, A; Hodell, D; Brenner, M; Anselmetti, F; Ariztegui, D; Mueller, A; Curtis, J; Grzesik, D; Burton, C and Gilli, A (2009) Re-evaluation of Climate Change in Lowland Central America During the Last Glacial Maximum Using New Sediment Cores from Lake Petén Itzá, Guatemala. In F. Vimeux et al. (eds.), Past Climate Variability in South America and Surrounding Regions, Developments in Paleoenvironmental Research 14

[16] Butzer, K (1989) Arqueología. Una Ecología del Hombre. EdicionesBellaterra. Barcelona.

[17] Clark, P, Marshall, A, Mix, A and Weaver, A (2004) Rapid Rise of Sea Level 19,000 Years Ago and Its Global Implications. Science Vol 304

[18] Correal y Van der Hammen (2001) Mastodontes en un humedal pleistocénico en el valle del Magdalena (Colombia) con evidencias de la presencia del hombre en el pleniglacial. Boletín de Arqueología. Volumen 16 № 1. Bogotá

[19] Dillehay T. (2002) Climate and Human Migrations. Science Vol 298

[20] Dillehay T, Ramírez C, Pino M, Collins M, Rossen J and Pino-Navarro J. (2008) Monte Verde Seaweed, Food, Medicine, and the Peopling of South America. Science Vol 320

[21] Dillehay TD, Ocampo C, Saavedra J, Sawakuchi AO, Vega RM, Pino M, et al. (2015) New Archaeological Evidence for an Early Human Presence at Monte Verde, Chile. PLoS ONE 10(11): e0141923. doi:10.1371/journal.pone.0141923

[22] Flantua, S. Hooghiemstra, H. Van Boxel, J. Cabrera, M. González-Carranza, Z y González-Arango, C 2014 Connectivity dynamics since the last glacial maximum in the northern Andes a pollen-driven framework to assess potential migration. En Paleobotany and Biogeography.

[23] Fiedel, S (1996). Prehistoria de América. Crítica Editorial. Barcelona.

[24] Fiedel, S (2000). The Peopling of the New World: Present Evidence, New Theories, and Future Directions. Journal of Archaeological Research, Vol. 8, No. 1,

[25] Goebel T, Waters M and O'Rourk D, (2008). The Late Pleistocene Dispersal of Modern Humans in the Americas Science Vol 319 
[26] González, C., Urrego L., y Martínez, J. (2006) Late Quaternary vegetation and climate change in the Panama Basin: Palynological evidence from marine cores ODP 677B and TR 163-38. Palaeogeography, Palaeoclimatology, Palaeoecology 234.

[27] Grobe, H, Huybrechts, P and Fûterer, D. (1993) Late Quaternary record of sea levels changes in the Antartic. GeolRundsch.

[28] Halligan, J. Waters, M. Perrotti, A. Owens, I. Feinberg, J. Bourne, M. Fenerty, B. Winsborough, B. Carlson, D. Fisher, D. Stafford Jr., T and Dunbar, J. (2016) Pre-Clovis occupation 14,550 years ago at the Page-Ladson site, Florida, and the peopling of the Americas. Science Advances.

[29] He, F. Shakun, J. Clark, P. Carlson, A. Liu, Z. Otto-Bliesner, B and Kutzbach, J. (2013) Northern Hemisphere forcing of Southern Hemisphere climate during the last deglaciation. Nature. Vol. 497

[30] Hohmann, G and Fruth, B (2003) Culture in Bonobos? Between-Species and WithinSpecies Variation in Behavior. Current Anthropology. Volume 44, Number 4.

[31] Hemming, S. (2004) Heinrich events massive late Pleistocene detritus layers of the north atlantic and their global climate imprint. Review of Geophysics, № 42.

[32] Herrera, L., Sarmiento, G., Romero, F., Botero, P. y BERRIO, J. (2001): Evolución ambiental de la depresión momposina (Colombia) desde el Pleistoceno Tardio a los Paisajes actuales. GeologíaColombiana, 26, Bogota

[33] Hodell, D., Anselmetti, F., Ariztegui, D., Brenner, M., Curtis J., Gilli, A., Grzesik, D., Guilderson, T., Mûller, A, Bush, M., Correa-Metrio, A., Escobar, J. and Kutterolf, S. (2008). An 85-ka record of climate change in lowland Central America. Quaternary Science Reviews 27. 1152-1165.

[34] Hooghiemstra, H., and Ran, E. (1994). Upper and Middle Pleistocene climatic change and forest development in Colombia: pollen record Funza II (2-158 m core interval). Palaeogeography, Palaeoclimatology, Palaeoecology, 109,

[35] Hooghiemstra, H. and Rahn, E. (1998) Upper and Middle Pleistocene climatic change and forest development in Colombia. pollen record Funza II (2-158 m core interval) Palaeogeography, Palaeoclimatology, Palaeoecology 109

[36] Ingólfsson, O. (2004). Quaternary glacial and climatic history of Antarctica. In Developments in Quaternary Science. Volume 2: Quaternary Glaciations: Extent and Chronology (edited by J. Ehlers, P.L. Gibbard). Elsevier, Amsterdam. 
[37] Johnson, A. y Earle, T. (2003) La Evolución de las Sociedades Humanas. Desde los grupos cazadores - recolectores al Estado agrario. Ariel Prehistoria. Barcelona

[38] Kelly, R (1995) TheForanging Spectrum. Diversity of hunter - gatherer lifeways. Smithsonianinstitutionpress. Washington.

[39] Laland, K. and Brown, G. (2006) Niche contruction human behavior and the adaptive lag hypothesis. Evolutionary Anthropology 15.

[40] Lanata, J., Martino, L., Osella, A. y García-Herbst, A. (2008) Ambiente y Demografía durante la Dispersión Humana Inicial en Sudamérica. En López C y Ospina G. Compiladores Ecología Histórica. Interacciones Sociedad - Ambiente a distintas escalas socio - temporales. UTP. Pereira

[41] Lee, R. (1979) The iKung San. Cambridge University Press. Cambridge.

[42] López, C. (2008) Landscape development and the evidence for early human occupation in the Inter-Andean tropical lowlands of Magdalena river, Colombia. Syllaba Pres. EBook

[43] López, C. (2019) Arqueología del Bajo y Medio río Magdalena: apuntes sobre procesos de poblamiento prehispánico de las Tierras Bajas tropicales interandinas de Colombia. Revista del Museo de La Plata. 4(2), pp. 275-304. https://doi.org/10.24215/25456377e078

[44] López, Carlos. E., \& Cano, Martha. C. (2011). En Torno a los Primeros Poblamientos en el Noroccidente de Suramérica: Acercamientos desde El Valle Interandino del Magdalena. Boletín de Arqueología Pontificia Universidad Católica de 1Perú, 15, 43-79.

[45] Masson-Delmotte, V., Stenni, B., Pol, K., et al. (2010). Epica Dome C record of glacial and interglacial intensities. Quaternary Science Reviews 29, 113-128.

[46] McGee, D., Donohoe, A., Marshall, J. and Ferreira, D. (2014). Changes in ITCZ location and cross-equatorial heat transport at the Last Glacial Maximum, Heinrich Stadial 1, and the mid-Holocene. Earth and Planetary Science Letters 390. 69-79.

[47] Marchant, R., Behling, H., Berrio, J.-C., Cleef, A., Duivenvoorden, J., Hooghiemstra, H., Kuhry, P., Melief, B., Schreve-Brinkman, E., Van Geel, B., Van der Hammen, T., Van Reenen, G. and Wille, M. (2002). Pollen-based biome reconstructions for Colombia at 3000, 6000, 9000, 12 000, 15000 and 18000 14C yr ago: Late Quaternary tropical vegetation dynamics. J. Quaternary Sci., Vol. 17 
[48] Mithen, S. (1996) Arqueología de la mente. Orígenes del arte, de la religión y de la ciencia. Crítica. Barcelona.

[49] Muñoz-García, M., Martín-Chivelet J., Rossi C., Ford, D andSchwarcz, H. (2007) Chronology of Termination II and the Last Interglacial Period in North Spain based on stable isotope records of stalagmites from CuevadelCobre (Palencia). Journal of Iberian Geology $33(1)$.

[50] Petit, J., Jouzel, J., Raynaud, D., Barkov, N., Barnola, J., Basile, I., Bender, M., Chappellaz, J., Davisk, M., Delaygue, G., Delmotte M., Kotlyakov, V., Legrand, M., Lipenkov, V., Lorius, C., Pépin, L., Ritz, C., Riouala, P. and Mackay, A. (2005) Diatom record of centennial resolution for the Kazantsevo Interglacial stage in Lake Baikal (Siberia). Global and Planetary Change № 46

[51] Reichel-Dolmatoff, Gerardo (1986). Arqueología de Colombia: un texto Introductorio. Fundación Segunda Expedición Botánica. Litografía Arco. Bogotá.

[52] Richter, D., Grün, R., Joannes-Boyau, R., Steele, T., Amani, F., Rué, M., Fernandes, P., Raynal, J.P., Geraads, D., Ben-Ncer, A., Hublin, J. J., and McPherron, S. (2017) The age of the hominin fossils from Jebel Irhoud, Morocco, and the origins of the Middle Stone Age. Nature 546. On line doi:10.1038/nature22335

[53] Saltzmank, E. and Stievenard, M. (1999). Climate and atmospheric history of the past 420,000 years from the Vostok ice core, Antarctica Nature Vol 399

[54] Sapolsky, R. (2006) Social Cultures among Nonhuman Primates.Current Anthropology Volume 47, Number 4.

[55] Sheinsohn, V. (2003). Hunter-Gatherer archaeology in South America. Annual Review of Anthropology.

[56] Stewart, J. and Stringer, C. (2012) Human Evolution Out of Africa: The Role of Refugia and Climate Change. Science Vol 335

[57] TarbuksE y Lutgens F (2008) Ciencias de la Tierra 8a ed. Pearson Educación. Madrid

[58] Thomas, M. (2008) Understanding the impacts of Late Quaternary climate change in tropical and sub-tropical regions. Geomorphology 101

[59] Toro, G. y Hermelin, M. (1995). Estudio comparativo de los paleoclimas en Colombia, Ecuador y Venezuela. En, Cambios cuaternarios en América del Sur. Por Argollo y Mourguiart (ed.) 
[60] Urrego, D. H., Hooghiemstra, H., Rama-Corredor, O., Martrat, B., Grimalt, J. O., Thompson, L., Bush, M. B., González-Carranza, Z., Hanselman, J., Valencia, B., and Velásquez-Ruiz, C.: (2016). Millennial-scale vegetation changes in the tropical Andes using ecological grouping and ordination methods, Climate of the Past, 12, 697-711

[61] Van der Hammen, T. y Absy, M. (1994) Amazonia during the last glacial. Palaeogeography, Palaeoclimatology, Palaeoecology 109.

[62] Van derHammen, T. y Hooghiemstra, H. (1995) The El AbraStadial, a Younger Dryas Equivalent in Colombia. Quaternary Science Reviews, Vol. 14

[63] Velásquez, C and Hooghiemstra, H. (2013) Pollen-based 17-kyr forest dynamics and climate change from the Western Cordillera of Colombia; no-analogue associations and temporarily lost biomes. Review of Palaeobotany and Palynology 194

[64] Waters M. and Stafford, T. W. (2013) The First Americans: A review of the evidence for the Late-Pleistocene peopling of the Americas. researchgate.net/publication/268149509

[65] Williams, S.J., 2009, Chapter C. Past, present, and future sea level rise and effects on coasts under changing global climate, in Lavoie, D., ed., Sand resources, regional geology, and coastal processes of the Chandeleur Islands coastal system-an evaluation of the Breton National Wildlife Refuge: U.S. Geological Survey Scientific Investigations Report 2009-5252, p. 37-46. 